\title{
Prescribed fire effects on biological control of leafy spurge
}

\author{
DAVID P. FELLOWS AND WESLEY E. NEWTON
}

Authors are wildlife biologist and statistician, respectively, U. S. Geological Survey, Northern Prairie Wildlife Research Center, 8711 37th St SE, Jamestown, N.D. 58401

\begin{abstract}
The flea beetle, Aphthona nigriscutis Foudras, is a potentially useful agent for biological control of leafy spurge (Euphorbia esula $\mathbf{L}$.) in grasslands devoted to wildlife conservation. However, effects of other grassland management practices on the persistence and dynamics of flea beetle populations are not well understood. We conducted small plot tests to evaluate 1) the effect of prerelease burning on establishment of $A$. nigriscutis colonies, and 2) the ability of established A. nigriscutis colonies to survive prescribed fire. More colonies established on plots that were burned prior to beetle release $(83 \%$ establishment) than on unburned plots $(37 \%$ establishment), possibly due to litter reduction and baring of the soil surface. However, most colonies established with the aid of fire did not survive past the first generation unless the habitat was otherwise suitable for the species, and we conclude that the primary benefit of prerelease burning is increased recruitment of $\boldsymbol{A}$. nigriscutis during the first few generations. Established colonies were not harmed by burns in October and May. Both spring and fall burns resulted in an increase in leafy spurge stem density during the first growing season, but stem density declined to the preburn level by the second growing season.
\end{abstract}

Key Words: Euphorbia esula, northern Great Plains, Aphthona nigriscutis, flea beetles

Leafy spurge (Euphorbia esula L.) is a major noxious weed on wildlife refuges, parks, waterfowl management areas, and other grasslands dedicated to biological conservation throughout the northern Great Plains (Wallace et al. 1992). Although studies are just beginning to document ecological impacts of leafy spurge (Belcher and Wilson 1989, Trammell and Butler 1995), the species' ability to form nearly monotypic stands (Watson 1985) clearly threatens native biodiversity.

Conventional chemical and physical control of leafy spurge is seldom practical on conservation lands because of cost (Messersmith and Lym 1983), risks to the native flora, or conflicts with the needs of wildlife. Biological control may thus be a preferred approach to control of leafy spurge on conser-

The authors thank N. Spencer, USDA-ARS, for providing beetles and assistance in study design. N. Spencer, R. Carlson, D. Larson, and G. Sargeant provided critical reviews of the draft manuscript.

Manuscript accepted 11 Nov. 1998.

\section{Resumen}

En pastizales dedicados a la conservación de fauna silvestre, el "Flea beetle" (Aphthona nigriscutis Foudras) es un agente potencialmente útil para el control del "Leafy spurge". Sin embargo, los efectos de otras practicas de manejo de pastizales en la persistencia y dinámica del "Flea beetle" no son bien entendidos. Se condujeron pruebas en parcelas pequeñas para evaluar: 1) el efecto de la quema antes de la liberación del insecto en el establecimiento de colonias de A. Nigriscutis y 2) la capacidad de las colonias establecidas de A. Nigriscutis para sobrevivir al fuego prescrito. Se establecieron mas colonias ( $83 \%$ de establecimiento) en las parcelas que se quemaron antes de la liberación de $\mathbf{A}$. Nigriscutis que en las parcelas sin quema $(37 \%)$, posiblemente debido a la reducción de mantillo y la desnudez de la superficie del suelo. Sin embargo, muchas de las colonias establecidas con ayuda del fuego no sobrevivieron pasada la primer generación, a menos que el hábitat fuera adecuado para la especie. Concluimos que el beneficio primario de la quema de preliberación es el incremento en el reclutamiento de A. nigriscutis durante las primeras generaciones. Las colonias establecidas no fueron dañadas por las quemas de Mayo y Octubre. Las quemas de primavera y otoño incrementaron de la densidad de tallos de "Leafy spurge" durante la primera estación de crecimiento, sin embargo, en la segunda estación de crecimiento, la densidad de tallos disminuyó al nivel existente antes de la quema.

vation lands, provided the control agent(s) is compatible with practices used to manage grassland habitats. Of primary concern is prescribed burning, which is widely used to manipulate prairie vegetation for the benefit of native communities (Higgins et al. 1989).

Flea beetles of the genus Aphthona (Coleoptera: Chrysomelidae) appear to be the most promising of the insects currently approved for biocontrol of leafy spurge in the U.S. (Rees and Spencer 1991). All but 1 approved Aphthona species are univoltine. Adults of univoltine species begin to emerge in mid- to late June and lay eggs in the soil near leafy spurge crowns until early September. Although adults feed on leafy spurge foliage, control is exerted by the larvae, which feed on leafy spurge roots. Larvae overwinter in the soil and pupate in late spring to early summer.

The univoltine A. nigriscutis Foudras appears generally adapted to upland soil types and moisture conditions on many wildlife management areas in the northern Great Plains (Rees 
and Spencer 1991). However, possibly because the litter layer interferes with reproduction, the species is difficult to establish in the dense, mixed stands of leafy spurge and grass that often prevail on these lands (N.R. Spencer, pers. comm).

The first objective of this study was to determine whether burning to remove the litter layer would facilitate establishment of A. nigriscutis. We tested both fall and spring burns to assess influence of burn season on establishment. This phase of the study also provided opportunity to assess initial combined effects of fire and beetle populations on leafy spurge stem density. Our second objective was to determine the ability of established colonies of $A$. nigriscutis to survive prescribed burns conducted during the early fall and late spring.

\section{Methods}

\section{General}

The study was conducted on U.S. Fish and Wildlife Service lands in south central and southeastern North Dakota. Study areas consisted of Arrowwood National Wildlife Refuge, Thiesen Marsh Waterfowl Production Area (WPA), and Walsh WPA in Stutsman Co.; Storhoff WPA in Barnes Co.; and Kemmer WPA in Cass Co. None of the study areas had been burned since at least 1985 .

On each study area, we delineated 2 blocks of six, 11-m diameter treatment plots. Blocks within a study area were separated by a minimum of $300 \mathrm{~m}$, and outer perimeters of adjoining plots within a block were separated by a minimum of $3 \mathrm{~m}$. Plots within a block were visually selected for similar topography, elevation, exposure, and vegetative cover, and plot centers were visually placed at the highest density of spurge. Each of 6 treatments was randomly assigned to 1 plot within each block. Treatments consisted of: beetles only (beetles released, no burning); fall preburn (burned in fall preceding beetle release); spring preburn (burned in spring preceding beetle release); fall postburn (burned in fall after beetles were confirmed to have established); spring postburn (burned in spring after beetles were confirmed to have established); and control (unburned, no beetles released).

We established 4 equally spaced per- manent transects radiating from the center to the perimeter of each plot. In July, 1993, we estimated leafy spurge height and stem density, depth of litter layer, and percent cover of leafy spurge, grasses, shrubs, forbs, and bare ground (Daubenmire 1959) at distances of 1, 3, and $5 \mathrm{~m}$ from the plot center on each of the transects. Leafy spurge stem densitywas estimated again at the same sampling points in July 1994 and 1995.

We used analysis of variance (ANOVA) to examine vegetation data collected in 1993. Our ANOVA model was a split-plot in a randomized block design. Study area by block combinations were considered random blocks, with plots being whole-units and distance from the center of the plot the subunit (Steel and Torrie 1980). Within distance classes, data from each plot were averaged across the transects. The general linear models procedure (PROC GLM) of SAS (SAS Institute Inc., 1989b) was used to conduct ANOVAs throughout this study. Exploratory distribution plots of all response variables did not indicate any violations of normality assumption; therefore all analyses were conducted in original units of measurement. Fisher's LSD procedure was used for multiple comparisons (Milliken and Johnson 1984). Reported means are least-squares means (SAS Institute, Inc. 1989b) unless stated otherwise. Statistical tests were considered significant at the 0.05 level.

\section{Experiment 1: Effects of prere- lease burning on establishment}

Fall-preburn and spring-preburn plots were burned on 14-21 Oct. 1993 and 5-11 May 1994, respectively. Spurge was dormant during fall burns, but actively growing $(8-30 \mathrm{~cm}$ tall) during spring burns. Burns removed 95-100\% (visual estimate) of standing vegetation and litter on all plots.

On 27-29 June 1994, we released 150 A. nigriscutis at the center of each falland spring-preburn, fall- and springpostburn, and beetle-only plot. Beetles used in the study were collected by the USDA Agricultural Research Station in Sidney, Mont., from the "Rugg" insectary (Glendive, Mont.) and were refrigerated until their release within 5 days after capture.

Beginning 13 June 1995, shortly after beetles began to emerge in $A$. nigriscutis insectaries at Northern Prairie Wildlife Research Center (Stutsman Co., N.D.), plots were swept once for beetles on each of 3 days at intervals of about 1 week during suitable weather (sunshine, dry vegetation, temperature $\geq 25^{\circ} \mathrm{C}$, wind $\leq 17 \mathrm{~km} / \mathrm{hr}$ ). A standard sweep sample consisted of 5 sweeps through the upper $25-30 \mathrm{~cm}$ of vegetation with a 39 -cm diameter sweep net on each of 5 equally spaced transects from the perimeter to the center of the plot, for a total of 25 sweeps. Captured beetles were counted and released immediately at the center of the plot. The greatest number of beetles captured on a plot in a standard sample during the 3 days was used as a population index for that plot.

In 1996, all plots on which beetles were collected in 1995, except those burned in experiment 2 (see below), were again swept for beetles 3 times beginning on 18 June to assess size of the second generation. Between 8-11 July 1996, a single auxiliary sample, consisting of 45-50 sweeps in a spiral pattern from the center to the edge of the plot, was taken on plots on which no beetles were found in standard sweep net samples in 1996. An auxiliary sample was also taken on plots where no beetles had been found in 1995 on the Storhoff, Walsh, Arrowwood, and Kemmer study areas.

Frequency of occurrence (number of plots with beetles established vs not established) was analyzed with chisquare tests of homogeneity (Dowdy and Weardon 1983) in 2-way tables. The categorical data modeling procedure (PROC CATMOD) of SAS (SAS Institute, Inc. 1989a) was used to conduct chi-square tests. ANOVA in a randomized block design (Steel and Torrie 1980) was used to assess the effects of treatments on beetle population index in 1995 because distance from center of plot was not taken into account for these data. Again, study area by block combinations were considered random blocks. We used split plot ANOVA to test for differences in vegetation between plots in which beetles became established and plots in which they did not. Each study plot was treated as a whole-plot. Observations within whole-plots were assigned to sub-plots according to their distance from the plot center. To examine joint treatment effects of fire and beetles on leafy spurge stem density from 1993 to 1994 and 1993 to 1995 , 
ANOVA was also used, with the model being as described for pre-treatment vegetation data above.

\section{Experiment 2: Effect of burning on established colonies}

Because few colonies were found on the postburn and beetle only plots in 1995 , the study was modified to test the effect of burning on established colonies. We selected the 12 plots with the greatest indicated Aphthona populations on the Storhoff, Kemmer, and Arrowwood study areas and randomly assigned 1 of 3 treatments (fall-burn, spring-burn, and unburned reference) to each of 4 plots. Most of these 12 plots were fall- and spring-preburn plots. Burns were conducted 11-23 Oct 1995 on the fall-burn plots and 13-16 May 1996 on the spring-burn plots; spurge phenology and results of burns were similar to those in 1993-94. Beginning on 6 June 1996, we swept all plots 3 times as described above. Changes in beetle population indexes from 1995 to 1996 by treatment were analyzed with ANOVA in a 1-way design, with plots nested within burn or reference groups.

\section{Results}

\section{General}

Herbicide drift from adjoining cropland top-killed varying percentages of leafy spurge on all Walsh block 1 ("Walsh-1") plots in June 1994. The fall-postburn plot on Storhoff-1 was lost to vandalism in the winter 1994-95. Data from these plots were excluded from all analyses.

Table 1. Mean initial vegetative conditions on 9 treatment blocks. Values are least-squares means.

\begin{tabular}{|c|c|c|c|c|c|c|c|}
\hline \multirow[b]{2}{*}{ Block } & \multicolumn{3}{|c|}{ Leafy Spurge } & \multirow{2}{*}{$\begin{array}{c}\text { Grass } \\
\text { Cover } \\
(\%)\end{array}$} & \multirow{2}{*}{$\begin{array}{c}\text { Forb } \\
\text { Cover } \\
(\%)\end{array}$} & \multirow{2}{*}{$\begin{array}{c}\text { Bare } \\
\text { Ground } \\
(\%)\end{array}$} & \multirow{2}{*}{$\begin{array}{c}\text { Litter } \\
\text { Depth } \\
(\mathrm{cm})\end{array}$} \\
\hline & $\begin{array}{c}\text { Density } \\
\left(\text { stems m}^{-2}\right)\end{array}$ & $\begin{array}{l}\text { Height } \\
(\mathrm{cm})\end{array}$ & $\begin{array}{c}\text { Cover } \\
(\%)\end{array}$ & & & & \\
\hline $\mathrm{A} 1^{1}$ & $173^{\mathrm{a}}$ & $35^{\mathrm{a}}$ & $59^{\mathrm{ab}}$ & $29^{\mathrm{ab}}$ & $2.7^{\mathrm{ab}}$ & $4.9^{\mathrm{a}}$ & $3.5^{\mathrm{ab}}$ \\
\hline A2 & $269^{\mathrm{a}}$ & $42^{\mathrm{a}}$ & $79^{c}$ & $33^{\mathrm{a}}$ & $2.5^{\mathrm{a}}$ & $2.7^{\mathrm{a}}$ & $4.7^{\mathrm{ab}}$ \\
\hline K1 & $148^{\mathrm{a}}$ & $39^{\mathrm{a}}$ & $60^{\mathrm{ab}}$ & $35^{\mathrm{b}}$ & $2.7^{\mathrm{ab}}$ & $3.3^{\mathrm{a}}$ & $4.6^{\mathrm{ab}}$ \\
\hline $\mathrm{K} 2$ & $222^{\mathrm{a}}$ & $35^{\mathrm{a}}$ & $68^{\mathrm{bc}}$ & $44^{\mathrm{b}}$ & $2.5^{\mathrm{a}}$ & $9.9^{\mathrm{b}}$ & $2.8^{\mathrm{a}}$ \\
\hline $\mathrm{S} 1$ & $142^{\mathrm{a}}$ & $41^{\mathrm{a}}$ & $69^{b c}$ & $46^{\mathrm{bc}}$ & $3.2^{\mathrm{bc}}$ & $3.7^{\mathrm{a}}$ & $5.1^{\mathrm{bc}}$ \\
\hline $\mathrm{S} 2$ & $203^{\mathrm{a}}$ & $37^{\mathrm{a}}$ & $60^{\mathrm{b}}$ & $34^{\mathrm{b}}$ & $3.7^{\mathrm{c}}$ & $5.5^{\mathrm{a}}$ & $5.5^{\mathrm{bc}}$ \\
\hline $\mathrm{T} 1$ & $148^{\mathrm{a}}$ & $42^{\mathrm{a}}$ & $65^{a b c}$ & $41^{b c}$ & $2.5^{\mathrm{a}}$ & $2.7^{\mathrm{a}}$ & $6.9^{\mathrm{c}}$ \\
\hline $\mathrm{T} 2$ & $129^{a}$ & $42^{\mathrm{a}}$ & $52^{\mathrm{a}}$ & $53^{c}$ & $2.5^{\mathrm{a}}$ & $2.5^{\mathrm{a}}$ & $6.2^{\mathrm{c}}$ \\
\hline $\mathrm{W} 2$ & $211^{\mathrm{a}}$ & $39^{\mathrm{a}}$ & $69^{b c}$ & $14^{\mathrm{a}}$ & $2.5^{\mathrm{a}}$ & $3.7^{\mathrm{a}}$ & $3.4^{\mathrm{ab}}$ \\
\hline $\mathrm{SE}^{2}$ & 34 & 2 & 5 & 7 & 0.2 & 1.1 & 0.8 \\
\hline
\end{tabular}

Block names: A=Arrowwood NWR, K=Kemmer WPA, S= Storhoff WPA, T=Thiesen WPA, W=Walsh WPA; numbers indicate block number.

${ }^{2}$ Pooled standard error for variable.

${ }^{\mathrm{a}-\mathrm{c}}$ Means within a column with different superscrpts are different $(\mathrm{p}<0.05)$. are least-squares means.

${ }^{\mathrm{T}}$ Pooled standard error for variable.
No pretreatment differences were detected among treatments for any of the vegetation variables measured in 1993 ( $\mathrm{p}>0.11)$. However, differences $(p<0.01)$ occurred among blocks for percent spurge cover, percent grass cover, percent forb cover, percent bare ground, and litter depth (Table 1). Leafy spurge stem density, height, and percent cover decreased, and grass percent cover increased, with increasing distance from center of plot $(\mathrm{p}<0.01$, Table 2$)$. No interactions were found between treatment and distance $(p>0.11)$ except for spurge height $(\mathrm{p}=0.03)$.

\section{Experiment 1}

In 1995 we collected $\geq 1$ beetle in standard sweep samples on 8 of 9 fall-preburn and 7 of 9 spring-preburn plots, compared to only 10 of 26 unburned plots. The proportion of plots on which $\geq 1$ beetle was captured (i.e. "colonized plots") did not differ between fall-preburn and spring-preburn plots $(\mathrm{p}=0.52)$, but was higher $(\mathrm{p}<0.01)$ on burned (fallpreburn and spring-preburn combined) than on unburned plots.

In 1995, mean population indexes (SE) were 1.9 (1.4), 9.9 (2.3), and 10.2 (2.3) for unburned, fall-preburn, and

.

5.

Table 2. Mean initial vegetative conditions at distances of 1,3 , and $5 \mathrm{~m}$ from plot center. Values

\begin{tabular}{lccccccc}
\hline \hline & \multicolumn{3}{c}{ Leafy Spurge } & & Grass \\
Distance & Density & Height & Cover & $\begin{array}{c}\text { Forb } \\
\text { Cover }\end{array}$ & $\begin{array}{c}\text { Bare } \\
\text { Ground }\end{array}$ & $\begin{array}{c}\text { Litter } \\
\text { Depth }\end{array}$ \\
\cline { 2 - 8 }$(\mathrm{m})$ & $\left(\right.$ stems m $\left.^{-2}\right)$ & $(\mathrm{cm})$ & $(\%)$ & $(\%)$ & $(\%)$ & $(\%)$ & $(\mathrm{cm})$ \\
1 & $193^{\mathrm{b}}$ & $40^{\mathrm{b}}$ & $69^{\mathrm{c}}$ & $34^{\mathrm{a}}$ & $2.7^{\mathrm{a}}$ & $3.4^{\mathrm{a}}$ & $4.8^{\mathrm{a}}$ \\
2 & $190^{\mathrm{b}}$ & $39^{\mathrm{ab}}$ & $64^{\mathrm{b}}$ & $36^{\mathrm{a}}$ & $2.8^{\mathrm{a}}$ & $5.6^{\mathrm{a}}$ & $4.8^{\mathrm{a}}$ \\
3 & $163^{\mathrm{a}}$ & $38^{\mathrm{a}}$ & $60^{\mathrm{a}}$ & $39^{\mathrm{b}}$ & $2.7^{\mathrm{a}}$ & $3.9^{\mathrm{a}}$ & $4.7^{\mathrm{a}}$ \\
$\mathrm{SE}^{1}$ & 6.4 & 0.4 & 1.2 & 1.1 & 0.1 & 0.7 & 0.2 \\
\hline
\end{tabular}

spring-preburn plots, respectively. Population indexes did not differ between the spring- and fall-preburn treatments $(\mathrm{p}=0.92)$, but were higher on burned than unburned plots $(\mathrm{p}<0.01)$. Comparison of treatment effects on population indexes using only colonized plots indicated the presence of larger populations on burned than unburned plots, with arithmetic means (SE) of 4.7 (3.3), 11.1 (3.0), and 13.1 (3.6) for unburned, fall-preburn, and spring-preburn plots, respectively.

The proportion of plots colonized varied among blocks (Table 3), suggesting that conditions were more suitable for beetles on some blocks than on others. Comparison of 1993 vegetation on colonized vs uncolonized plots using only the unburned plots revealed differences in litter depth (means of $3.6 \mathrm{~cm}$ colonized, $5.1 \mathrm{~cm}$ uncolonized, $\mathrm{p}=0.05)$ and percent bare ground $(5.7 \%$ colonized, $3.0 \%$ uncolonized, $\mathrm{p}=0.02)$. No other differences in vegetation were found between colonized and uncolonized plots $(\mathrm{p}>0.10)$. Comparison of Tables 1 and 3 suggests a positive correspondence between overall colonization success and mean percent bare ground on the 9 blocks; bare ground averaged $5.5-9.9 \%$ on blocks Storhoff-2 and (n) 2 , where beetles established on all plots, 3.7-4.9\% on Arrowwood-1, Storhoff-1, and Walsh-2, where some unburned plots and all of the burned plots were colonized, and $2.5-3.3 \%$ on the remaining blocks, where none of the unburned, and only some of the burned, plots were colonized. No such relationship was apparent for litter depth.

Eight of 25 colonized plots were burned in fall 1995 or spring 1996 to evaluate effects of burning on established colonies (see experiment 2). Among the remaining 17 colonized plots that were not burned for experiment 2, standard sweep samples in 1996 indicated that populations had increased 
Table 3. Colony establishment by block and treatment. Block designations as in Table 1.

\begin{tabular}{lcc}
\hline \hline Block & Unburned & Burned \\
\hline & \multicolumn{2}{c}{ (no. colonized/n. plots) } \\
K2 & $3 / 3$ & $2 / 2$ \\
S2 & $3 / 3$ & $2 / 2$ \\
A1 & $2 / 3$ & $2 / 2$ \\
S1 & $1 / 2$ & $2 / 2$ \\
W2 & $1 / 3$ & $2 / 2$ \\
T2 & $0 / 3$ & $1 / 2$ \\
K1 & $0 / 3$ & $1 / 2$ \\
A2 & $0 / 3$ & $1 / 2$ \\
T1 & $0 / 3$ & $1 / 2$ \\
\hline
\end{tabular}

or remained constant on 5, and decreased or gone extinct on 6 , of the preburn plots. Similar results were noted on the unburned plots, with 3 populations increasing or stable and 3 declining or extinct.

Auxiliary samples in 1996 revealed presence of small populations (1-7 captures/plot) on 4 of 8 plots where beetles were captured in standard sweep samples in 1995 but not in 1996. No beetles were collected in auxiliary samples in 1996 on any of the plots where no beetles were detected in standard sweep samples in 1995.

Joint treatment effects of fire and beetles on leafy spurge stem density from 1993 to 1994 and 1993 to 1995 are compared in Table 4, first using all plots, and then using only plots on which beetles were detected in both 1995 and 1996. Both data sets indicate that stem density increased more $(\mathrm{p}<0.01)$ on the burned than on the unburned plots in 1994, but that the net change from 1993 to 1995 did not differ between treatments $(\mathrm{p}>0.30)$. Distance from plot center had no effect on change in stem density, and no distance $\mathrm{x}$ treatment interaction was found in any of the comparisons ( $p>0.29)$.

\section{Experiment 2}

Beetles were collected in standard sweep samples in 1996 on all 12 plots

Table 4. Change in mean number of leafy spurge stems $\mathrm{m}^{-2}$ (SE) by treatment and year. Values are least-squares means.

\begin{tabular}{lrrrrrrr}
\hline \hline & \multicolumn{3}{c}{ All Plots } & & \multicolumn{3}{c}{ Beetles Present 1995 \& 1996 } \\
\cline { 2 - 3 } \cline { 6 - 7 } Treatment & \multicolumn{1}{c}{1993 to 94} & 1993 to 95 & & $\mathrm{n}$ & 1993 to 94 & 1993 to 95 \\
\hline & 9 & $11.9(24.1) \mathrm{a}$ & $18.9(23.3) \mathrm{a}$ & & 7 & $13.8(24.6) \mathrm{a}$ & $24.8(21.4) \mathrm{a}$ \\
Control & 26 & $21.6(13.9) \mathrm{a}$ & $5.7(13.8) \mathrm{a}$ & & 7 & $31.7(24.6) \mathrm{a}$ & $-20.2(21.4) \mathrm{a}$ \\
Unburned & 9 & $135.4(24.1) \mathrm{b}$ & $37.0(23.3) \mathrm{a}$ & & 5 & $141.7(29.1) \mathrm{b}$ & $31.3(25.3) \mathrm{a}$ \\
Fall preburn & 9 & $110.1(24.1) \mathrm{b}$ & $24.5(23.3) \mathrm{a}$ & & 5 & $124.8(29.1) \mathrm{b}$ & $33.7(25.3) \mathrm{a}$ \\
Spring preburn & 9 & &
\end{tabular}

${ }^{a-b}$ Means within a column with different superscripts are different $(\mathrm{p}<0.05)$. used to evaluate effects of fire on established colonies. Populations increased on 10 plots and decreased on 2 plots (1 reference and 1 spring-burn). Mean increase in number (SE) of beetles captured from 1995 to 1996 was 51.5 (33.3), 70.8 (33.3), and 36.8 (33.3) for unburned, fall-burn, and spring-burn plots, respectively. Treatment differences were not significant $(\mathrm{p}=0.77)$.

\section{Discussion}

Prerelease fall or spring burning enhances colonization by A. nigriscutis. Although results of auxiliary samples indicate that standard sweep samples may have failed to detect some small populations in 1995, none was sufficiently established to persist into the second year.

Benefits of burning may be short-lived if habitat is unsuitable for other reasons. Beetles established on only 1 of 15 unburned plots on Walsh-2, Thiesen-1 and -2, Kemmer-1, and Arrowwood-2, (Table 3 ) suggesting that unburned habitat on these blocks was unsuitable for $A$. nigriscutis. Five of 7 colonies detected on preburned plots on those blocks in 1995 failed to survive into 1996 . In contrast, on Kemmer-2, Storhoff-2, and Arrowwood-1, where beetles established on 8 of 9 unburned plots, all colonies on preburned plots persisted into 1996.

The positive effect of bare ground and the negative effect of litter depth on colonization suggested by our data support the hypothesis (N.R. Spencer, pers. comm.) that A. nigriscutis may be limited in part by factors that impede access to the soil surface. If litter reduction and/or exposure of bare soil are the primary mechanisms facilitating establishment on burned sites, rapid litter buildup and plant regeneration following a burn may cause benefits to be only transitory even in relatively good $A$. nigriscutis habitat. However, as long as the habitat is otherwise suitable, increased early recruitment from prerelease burning should ultimately enhance control.

One possible objection to prerelease burning concerns potential effects of fire on leafy spurge. Wolters et al.(1994) reported increased leafy spurge stem density in the first growing season following spring (4 May), but not fall (19 Sept.), burns in southwestern North Dakota. Thus, a spring burn followed by an unsuccessful beetle release might leave the manager with an even denser stand of leafy spurge. We observed significant increases in stem density during the first growing season after both spring and fall burns (Table 4). However, the increases did not persist into the second growing season.

It is unlikely that beetles caused the observed decline in stem density on burned plots from 1994 to 1995. Populations were low on most plots in 1995, and stem counts declined uniformly throughout each plot, whereas beetles were concentrated at the plot center. Although Wolters et al.(1994) concluded that fire reduces germination rate of leafy spurge seed, we believe most of the increase in 1994 consisted of a flush of seedlings, which subsequently died due to competition with established plants(Hanson and Rudd 1933, Selleck et al. 1962).

No control of leafy spurge relative to pretreatment stem density was evident with any treatment in the first year after beetles were released, and the unanticipated need to reburn the most successful colonies prevented meaningful assessment of control during the second year. Given the small founding populations used in this study, lack of control during the first year was not unexpected.

However, results from leafy spurgeinfested fields at Northern Prairie Wildlife Research Center indicate that prerelease burning can have immediate control benefits when larger numbers of beetles are released. As part of an operational control program (Fellows, Unpublished data), releases of approximately 1,000 A. nigriscutis were made in July 1996, at intervals of about 25 m throughout a habitat unit where the species was known to do well. Approximately half of the unit had been burned in early June 1996. The remainder had not been burned since at least 1967. In late May 1997, we estimated 
the size of the spurge-free zone at each release site. For 25 sites in the burned habitat, the mean spurge-free radius (SE) was 93 (12) cm, compared to a mean of $36(9) \mathrm{cm}$ at 10 unburned sites. Mean values at reference sites midway between adjacent release sites were 11 (1) $\mathrm{cm}$ in the burned and 15 (1) $\mathrm{cm}$ in the unburned zone.Thus beetles on average cleared nearly 7 times more spurge in the burned $\left(2.7 \mathrm{~m}^{2}\right)$ than in the unburned $\left(0.4 \mathrm{~m}^{2}\right)$ habitat during the first year. Additionally, zones of reduced stem density and stunting extended for 3-4 $\mathrm{m}$ around most of the sites in the burned, but not in the unburned area.

Because economics and long-term control benefits of preburning fields solely to enhance establishment of $A$. nigriscutis have not been determined, we cannot currently recommend that prerelease burning be adopted as an operational practice. However, managers should take advantage of scheduled management burns in leafy spurgeinfested fields by releasing A. nigriscutis into suitable habitat within the burned area whenever possible.

Our results also demonstrate that established A. nigriscutis colonies in North Dakota can survive burns from early October through mid-May. No difference was found in the population indexes of burned and unburned plots, suggesting that burning had no negative effect on larval survival and eclosure rates. Moreover, based on the response of beetles to preburned release sites, we anticipate that periodic burning at appropriate times will enhance expansion of established colonies and lead to earlier control of leafy spurge.

Spring burning of established colonies must be completed early enough to allow spurge to regrow before beetles emerge. Based on regeneration observed in this study, adequate spurge would probably be available in southeastern North Dakota following burns as late as 25 May in most years. However, assuming regeneration is moisture dependent, a target cutoff date of 15 May is recommended during dry years. Elsewhere, the spring cutoff should be adjusted to match the anticipated local adult emergence pattern and rates of foliar regeneration.

Because egg laying is complete by early September (Rees and Spencer 1991), fields containing A. nigriscutis can likely be burned as early as 1
September without damage to colonies. Even earlier burning, if needed to meet grassland management objectives, may have no negative effect. Brinkman (1997) found peak insemination rates in early July and few adults by early August at an A. nigriscutis insectary near Pollock, South Dakota. Burning as early as 1 August may therefore not substantially reduce egg production. However, because mid-summer burning could affect the nutrient value of spurge or increase soil insolation beyond larval tolerance, early burning should be approached with caution.

\section{Literature Cited}

Belcher, J.W. and S.D. Wilson. 1989. Leafy spurge and the species composition of a mixed-grass prairie. J. Range Manage. 42:172-175.

Brinkman, M. 1997. Reproductive status of established black dot flea beetle (Aphthona nigriscutis) populations in South and North Dakota. Leafy Spurge News 19:2.

Daubenmire, R. 1959. A canopy-coverage method of vegetational analysis. Northwest Sci. 33:43-64.

Dowdy, S. and S. Weardon. 1983. Statistics for research. John Wiley and Sons, Inc. New York, N.Y.

Hanson, H.C. and V.E. Rudd. 1933. Leafy spurge life history and habits. N.D. Agr. Exp. Sta. Bull. 266.

Higgins, K.F., A.D. Kruse, and J.L. Piehl. 1989. Prescribed burning guidelines in the northern Great Plains. USFWS and Coop. Ext. Serv., S. Dak. State Univ., USDA EC760.

Messersmith, C.G. and R.G. Lym. 1983. Distribution and economic impacts of leafy spurge in North Dakota. N.D. Farm Res. 40:8-13.

Milliken, G.A. and D.E. Johnson. 1984. Analysis of messy data, Vol. 1: designed experiments. Van Nostrand Reinhold, New York, N.Y.

Rees, N.E. and N.R. Spencer. 1991. Biological control of leafy spurge, $p$. 182-192. In: L.F. James, J.O. Evans, M.H. Ralphs, and R.D. Child [eds], Noxious Range Weeds. Westview Press. Boulder, Colo.

SAS Institute, Inc. 1989a. SAS/STAT user's guide, version 6, 4th ed., Vol. 1. SAS Institute, Inc. Cary, N.C.

SAS Institute, Inc. 1989b. SAS/STAT user's guide, version 6, 4th ed., Vol. 2. SAS Institute, Inc. Cary, N.C.

Selleck, G.W., R.T. Coupland, and C. Frankton. 1962. Leafy spurge in Saskatchewan. Ecol. Monog. 32:1-28.

Steel, R.G.D. and J.H. Torrie. 1980. Principles and procedures of statistics: a biometrical approach, 2nd ed. McGrawHill Book Co. New York, N.Y.
Trammell, M.A. and J.L. Butler. 1995. Effects of exotic plants on native ungulate use of habitat. J. Wildl. Manage. 59:808-816.

Wallace, N.M., J.A. Leitch, and F.L. Leistritz. 1992. Economic impact of leafy spurge on North Dakota Wildland. Ag. Econ. Rep. 281, Agr. Exp. Sta., N.D. State Univ. Fargo, N.D.

Watson, A.K. 1985. Introduction: the leafy spurge problem, p. 1-6 In: A.K. Watson,(ed.) Leafy Spurge. Weed Sci. Soc Amer. Monogr. 3.

Wolters, G.L., C. Hull Sieg, A.J. Bjugstad, and F.R. Gartner. 1994. Herbicide and fire effects on leafy spurge density and germination. USDA, USFS, Rocky Mountain Forest and Range Exp. Sta. Res. Note RM-526. 5pp. 